\title{
The Correlates of the Resilience of the Children of Alcoholics
}

\author{
Iwona Grzegorzewska, Marzanna Farnicka \\ University of Zielona Góra, Zielona Góra, Poland \\ Email: i.grzegorzewska@wnps.uz.zgora.pl,m.farnicka@wpsnz.uz.zgora.pl
}

Received September $30^{\text {th }}, 2013$; revised October $28^{\text {th }}, 2013$; accepted November $25^{\text {th }}, 2013$

\begin{abstract}
Copyright (C) 2013 Iwona Grzegorzewska, Marzanna Farnicka. This is an open access article distributed under the Creative Commons Attribution License, which permits unrestricted use, distribution, and reproduction in any medium, provided the original work is properly cited. In accordance of the Creative Commons Attribution License all Copyrights (C) 2013 are reserved for SCIRP and the owner of the intellectual property Iwona Grzegorzewska, Marzanna Farnicka. All Copyright $(2013$ are guarded by law and by SCIRP as a guardian.
\end{abstract}

\begin{abstract}
Objective: The aim of the article was to describe the process of resilience in school children of alcoholics. Additionally, it was important to determine how risk and protective factors, personal resources and the social environment (within the family and without) determine the occurrence of positive adaptation. Methods: The study involved 182 children in two comparison groups (children of alcoholics and children of non-alcoholics) in aged $9-12$. The clinical group consisted of 90 children from families with alcohol problems highlighted on the basis of a CAST screening test. The control group comprised 92 people from families without alcohol problems. An expression of the resilience of children of alcoholics was the level of a positive adaptation, as measured by two indicators: developmental tasks and life satisfaction. There has also been measuring individual and environmental predisposition. Results: The results pointed to the need for the adaptation of therapeutic and preventive treatment to the current stage of development as indicated by developmental tasks.
\end{abstract}

Keywords: Alkoholics Family; Children; Resiliance; Positive Adaptation

\section{Introduction}

For years, children of alcoholics have been a focus of study for clinical psychologists. This is due, on the one hand, to an unfortunately high incidence of alcoholism in modern society; and on the other hand, to the notably specific functioning of those families which suffer from alcohol problems. Our knowledge and understanding of the psychology of children of alcoholics is constantly increasing and improving. Today, we know that the offspring of parents addicted to alcohol are typically characterized by an increased susceptibility to a variety of problems (Caspi et al., 1996; the National Institute on Alcohol Abuse and Alcoholism, 2000), and that genetic factors influence $40 \%-60 \%$ of the variance of risk of alcoholism (Heath et al., 1997; Kendler et al., 1994). However, it must be stressed that some children of alcoholics develop properly, going on to lead a satisfactory life free from mental disorders or issues (Zucker et al., 2003; Hitzeg et al., 2008; Jordan, 2010).

The increased problem susceptibility of the children of alcoholics is rooted in biological and psychosocial factors. Susceptibility to alcohol abuse is affected by hereditary conditions within the population. However, the gene responsible for alcoholism has not yet been discovered, something which would prove to be a spectacular event in the field of alcoholism research. The complexity and diversity of the phenotypic picture of alcoholism, in principle, may preclude the existence of a single specific gene which is responsible for the disorder associated with alcohol abuse. However, progress in the mapping of the human genome is increasingly moving us towards an understanding of the relationship between the structure of chromosomes and the metabolism of alcohol in the body (Higuchi et al., 1992), which has a seemingly significant impact on drinking behavior.

The second source of vulnerability is due to psychosocial factors; the increased amount of negative life stress plays a role in the development of problematic behaviors in the children of alcoholics. From such a perspective, vulnerability may be viewed as the result of specific alcoholic and non-alcoholic interactions of parents with their offspring (Jacob \& Johnson, 1997). The effects of alcohol are specifically related to a range of factors, such as: the unconscious process of identification and modeling, imitation of parental drinking habits, growth expectations associated with the consumption of alcohol and other aspects of the parent-child relationship (Chassin et al., 1993; Zucker et al., 1995). These factors are of particular importance in the development of the problem of addiction in the offspring of alcoholics.

However, non-alcoholic related issues can also have an influence on the more general characteristics of the family environment, such as the under-fulfillment of the role of the parent, distorted patterns of parent-child relationships or other comorbid psychiatric disorders in the parents. These act as risk factors which increase the likelihood that children of alcoholics may develop a whole spectrum of mental disorders, illegal behavior, and inappropriate social norms, including alcoholism. This is primarily why alcoholism is associated with antisocial personality types and the development of depression (Ellis, Zucker, \& Fitzgerald, 1997). Although the research carried out in both fields uses different procedures and focuses on different factors, the authors (e.g., Ellis et al., 1997; McGue, 1997) are usually quick to emphasize that an individual's susceptibility to the development alcoholism-related psychological disorders is 
typically the result of interactions between genetic and environmental factors.

An increasing number of studies carried out on the children of alcoholics is increasingly contributing to a better understanding of the process of development and its determinants in the offspring of addicted parents. Research undertaken from the perspective of developmental psychopathology has led to the discovery of the phenomenon of resilience in the children of alcoholics (Werner \& Smith, 1982; Zucker et al., 2003). The concept of resilience, or toughness, explains the phenomenon of positive adaptation in young people who are at risk of experiencing adverse life events. It focuses on explaining the importance of the factors and mechanisms that protect an individual, and how these factors impact the final results of development. In the literature, and there is considerable variation in the terminology for the development of resilience (see Kaplan, 2005); however, most researchers are inclined to regard this concept not as a permanent feature of the child, but as a multifactorial, dynamic process of dealing with adverse conditions, in turn leading to the development of a positive adaptation (Luthar et al., 2000).

Positive adaptation is one of the key concepts essential for understanding the course of the development of children raised in inadequate living conditions. It refers to a multidimensional process in which the individual uses his mental capabilities and environmental resources to adapt to the requirements of the next phase of development. Positive adaptation is considered to be the product of mutual interaction between an individual's characteristics (biological and psychological), the history of previous adaptations and development within the current phase of life and environmental setting (Boyce et al., 1998; Sroufe, 1997; Cichetti, 2006). The assessment of adaptations in those children at risk of difficult lives can be carried out in several dimensions. Most often it is done within the contextual framework of a number of factors, including: developmental (level of performance and development) and positive (a feeling of wellbeing). In light of this, the main objective of this study was to determine an effective understanding of the path of development of children of alcoholics, that is, to identify at what stages of life there are distinct behaviors indicative of positive adaptation, and how risk factors and the nature of personal resources and environmental factors (within the family and without) determine the occurrence of such adaptations at different stages of life.

\section{Materials and Methods}

Subjects: A total of 182 children in two comparison groups (children of alcoholics and children of non $=$ alcoholics) in school age ( 9 - 12 years). The clinical group consisted of children from families with alcohol problems highlighted on the basis of a CAST screening test. 90 patients were examined. The control group comprised 92 people from families without alcohol problems. The groups had a similar distribution of gender. The classification of a person in the research was associated with the fulfillment of specific criteria relevant from the perspective of the model test. The alcohol group was: 1) an alcoholic father; 2) a full family; 3) parents who did not report any other (nondependence) symptoms of psychopathology. The qualification for the control group consisted of the following criteria: 1) upbringing within a complete family; 2) a lack of psychiatric disorders, including alcoholism in the parents of the patients. The control group was created from the associated selection of students.

Test procedure: The study was carried out individually, or in small groups. People were recruited to the study through substance-abuse treatment centers, community centers, and school counselors. The testing procedure consisted of two stages. After qualifying for research, permission and consent of the parents of minors or individuals in the study was obtained. Then the subjects proceeded to the actual test. The subjects were expected complete a set of questionnaires designed to measure the variables under consideration.

Variables: An expression of the adaptation of children of alcoholics (dependent variable) was the level of such an adaptation, as measured by two indicators: 1) developmental tasks; and 2) life satisfaction. Individual predispositions, including personality (independent variables) included: temperament, attachment, resiliency and coping with stress. Environmental predispositions were related to family and out-family support, with additional activities outside of this community.

Research tools: The study used tools to measure the risk variable (family with alcohol problems), the dependent variables of positive adaptation, and the independent variable of individual predisposition.

Risk assessment: CAST Screening Test (Jones, 1983).

\section{Assessing Positive Adaptation}

Implementation of the development: Questionnaire for Attainment of Developmental Tasks (QADT) by Grzegorzewska (2006). The QADT has sound psychometric properties, reliability coefficients obtained for a sample of 120 , range from 0.77 to 0.92 (Grzegorzewska, 2006); Sense of life satisfaction: the Students' Life Satisfaction Scale (Brief Multidimensional Students' Life Satisfaction Scale). Coefficient alphas in the 0.70 0.80 range have consistently been reported across all age groups. Test-retest reliability has also been established with correlations of 0.76 across 1 - 2 weeks (BMSLSS; Seligson, Huebner, \& Valois, 2003).

\section{Assessing Individual Abilities}

Resiliency: Resiliency Scales for Children and Adolescents, by Prince-Embury (2006). The standardization sample included 200 children ages 15 through 18 years matched to the U.S. census by ethnicity and by parent education level within sex and age band. Chronbach's alpha coefficients ranged from 0.93 to 0.95 for the total sample and for males and females indicating good internal consistency. The standard error of measurement ranged from 0.90 to 2.45 for the total sample on all subscales indicating good reliability. Temperament: the EAS Temperament Questionnaire by A. H. Bussa and R. Plomina-Polish adaptation by W. Oniszczenko (1997) The method has satisfactory psychometric indicators (a Cronbach: 0.57 - 0.74; reliability indicators: $0.71-0.84$ ) (Oniszczenko, 1997). Attachment: the Inventory of Parent and Peer Attachment (IPPA) by Armsdena and Greenberg (1987) with two subscales. Reliability: three week test-retest reliabilities for a sample of 2718 to 20 -year-olds were 0.93 for parent attachment and 0.86 for peer attachment.For the revised version, internal reliabilities (Cronbach's alpha) are: Mother attachment, 0.87; Father attachment, 0.89; Peer attachment, 0.92. Strategies for coping with stress: the "How are you coping?" scale (JSR) by Siegfried Juczyńskiego and Nina Ogińska-Bulik (2009). The stan- 
dardization sample included 400 children ages 11 through 17 years and achieved good reliability and validity indexes. Chronbach's alpha coefficients ranged from 0.85 - 0.87. Six week test-retest reliabilities for a sample of 35 for dispositional and situational strategies were: 0.83 and 0.76 for Activity Coping; 0.70 and 0.65 for Focus on Emotion, and 0.84 and 0.73 for Seeking Support strategies. School Skills: measured by a grade point average according to latest school reports and certificates.

\section{Estimating Environmental Suitability}

Social support: the Child and Adolescent Social Support Scale (CASSS) by Demaray, Malecki, Elliot (2000). Reliability: Coefficient Alpha for Total Frequency Scale was 0.96 - 0.97 for middle school grades 5 - 8 and 0.97 for high school grades 9-12. Activity capacity: five individual questions regarding sporting activities and hobbies, levels of engagement in these activities and membership of organizations, clubs, teams or informal groups. Responses were graded from 0 to 4 , the maximum score attainable being 20. Negative life events: The scale of life experiences for children and youth (Grzegorzewska, 2006), allowing for the assessment of normative and non-normative events in the following four areas: education, social-familial and social-extrafamilial relationships, as well as traumatic and exceptional events. The tool belongs to the ordinal scale type. Through its use, the following LES indicators can be computed: 1) the number of negative experiences/events as perceived by the subject; and 2) the intensity of these experiences (Grzegorzewska, 2006).

\section{Results}

In order to better answer the research questions, the statistical analysis of the results included: 1) Distinguishing two different groups through the use of the k-means clustering technique. Those groups differed in their health profiles. This was done to provide an estimation of the likelihood (through an odds-ration) that a number of children of alcoholics would display highadaptation characteristics; 2) a determination of whether highlyadaptive children differ from less-adaptive children-measured in terms of individual abilities and environmental factors; 3) a determination of positive adaptations in children of alcoholics using multiple regression prediction.

\section{Positive Adaptation in Children of Alcoholics}

The first step in the analysis was to determine how the test subjects cope with adapting to appropriate life and development conditions. For this purpose, the k-means clustering technique was used to create two groups of differing health profiles. The profiles were extracted from the four quantitative variables which characterize resilience: the developmental tasks and a sense of satisfaction in life. An analysis of the main components showed that there are two essential elements: high and low adaptation. Profile 1 (high-adaptation) - is characterized by young people who gave good results for the two measured aspects of mental health and display a good level of adaptation. They are characterized by a higher level of development taks and sense of life satisfaction. Profile 2 (low-adaptation)-is characterized by young people who displayed a weaker performance in relation to the measured aspects of resilience along with a poor level of adaptation. The distribution of the population of the various profiles obtained in the control group and during the research, taking into account the age of participants in the study, is presented in Table 1.

The table shows that, those subjects who were the children of alcoholics are more frequently classified as belonging to the low-adaptation (2) category in comparison to those of the control group where there is a higher percentage of highly-adaptive (1) profiles. The high-adaptation profile is represented by $38.9 \%$ of the children of alcoholics, and $65.2 \%$ of the children in the control group. The low-adaptation profile consisted of $61.1 \%$ of children from alcoholic families and $34.8 \%$ of the control group. If the father of a family of the child of school age is abusing alcohol, the odds ratio that qualified for the highadaptation profile (Profile 1) was: $\mathrm{OR}=0.5895 \%$; $\mathrm{CI}=0.34$ 0.97 , and for children from families with no alcohol problem, the ratio was: $\mathrm{OR}=1.795 \% \mathrm{CI}=1.02-2.88$ (see Table 2).

The next step in the analysis was to determine whether there are differences in the high (1) and low (2) adaptive profiles of children of alcoholics, measured in terms of individual and social attitudes, and to determine what factors lead to a maintaining of health, and any disturbance of adaptation of their lives. Comparisons between children of alcoholics from the low-adaptation profile and the high-adaptation profile were performed using Student's t test. Along with a hierarchical method, a stepwise multiple regression procedure was used to determine any correlates of positive adaptation among the children of alcoholics.

\section{Determinants of Positive Adaptation in Children of Alcoholics at School Age}

Firstly, we sought to answer the question of whether there are differences between the high (1) and low (2) adaptation profile subjects at school age in regards to the measurement of individual and social abilities.

\section{Individual Predispositions}

Comparisons were made between subject profiles with re-

Table 1.

The Distribution of the various adaptive profiles obtained in the control group and during research, taking into account the age of the respondents.

\begin{tabular}{|c|c|c|c|c|c|}
\hline \multirow{2}{*}{\multicolumn{2}{|c|}{ Age Group }} & & \multicolumn{2}{|c|}{ Research Groups } & \multirow[t]{2}{*}{ Total } \\
\hline & & & $\begin{array}{l}\text { Children of } \\
\text { Alcoholics }\end{array}$ & $\begin{array}{l}\text { Control } \\
\text { Group }\end{array}$ & \\
\hline \multirow{4}{*}{ Adaptation profile } & 1 & Number & 35 & 60 & 95 \\
\hline & & $\begin{array}{l}\% \text { of } \\
\text { group }\end{array}$ & $38.9 \%$ & $65.2 \%$ & $52.2 \%$ \\
\hline & 2 & Number & 55 & 32 & 87 \\
\hline & & $\begin{array}{l}\% \text { of } \\
\text { group }\end{array}$ & $61.1 \%$ & $34.8 \%$ & $47.8 \%$ \\
\hline Total & & Number & 90 & 92 & 182 \\
\hline$\chi^{2}(1)=11.61 ; p=0.001$ & & & & & \\
\hline
\end{tabular}

Table 2.

The odds ratio for qualifying individuals to the high-adaptation profile.

\begin{tabular}{ccc}
\hline & Children of Alcoholics & Control Group \\
\hline School Age & OR $=0.58$ & OR $=1.7$ \\
& $95 \%$ CI $=0.34-0.97$ & $95 \% \mathrm{CI}=1.02-2.88$ \\
\hline
\end{tabular}


gard to the following variables: attachment, temperament, coping with stress and resiliency. In the comparison of the mother attachment variable it occurred that children of school age showed differences between all measured aspects of attachment to the mother: maternal bond $(\mathrm{t}(1.180)=3.82, p<0.001, \mathrm{~d}=$ $0.85)$, confidence $(\mathrm{t}(1.180)=5.71, p<0.001, \mathrm{~d}=1.3)$, communication $(\mathrm{t}(1.180)=6.45, p<0.001, \mathrm{~d}=1.5)$ and alienation $(\mathrm{t}(1.180)=-4.14, p<0.001, \mathrm{~d}=0.8)$. The effect size clearly indicates that the differences are considerable. Those subjects from the high-adaptation profile (Profile 1) are characterized by a higher level of relationship with the mother: $(\mathrm{M}=37.57, \mathrm{SD}$ $=7.03$ ); as compared to those from the low-adaptation profile (Profile 2): $(\mathrm{M}=31.47, \mathrm{SD}=7.59)$. They also express a higher level of confidence in the mother herself $(\mathrm{M}=37.8, \mathrm{SD}=6.4)$ than those who have problems with adaptation $(\mathrm{M}=28.58$, SD $=8.05$ ). Similarly, the patterns of the quality of communication with the mother are reflective of this trend; higher in the high-adaptation profile (Profile 1) $(\mathrm{M}=35.37, \mathrm{SD}=6.92)$ and lower in the low-adaptation profile (Profile 2$)(\mathrm{M}=25.4, \mathrm{SD}=$ 7.3). Meanwhile, those subjects who are well adapted display significantly less alienation to the mother $(\mathrm{M}=12, \mathrm{SD}=3.69)$ than the low-adaptation profile subjects $(\mathrm{M}=15.8, \mathrm{SD}=4.6)$.

Comparisons between the profiles with regards to the temperament variable show that within the school-age group there were no significant differences with respect to the emotionality variable $(\mathrm{t}(1.180)=-4.88, p<0.001, \mathrm{~d}=0.9)$, activity $(\mathrm{t}(1.180)$ $=3.56, p<0.001, \mathrm{~d}=0.6)$, sociability $(\mathrm{t}(1.180)=4.88, p<$ $0.001, \mathrm{~d}=0.9)$, and shyness $(\mathrm{t}(1.180)=-2.66, p<0.01, \mathrm{~d}=$ $0.4)$. Among the high-adaptation profile, as compared to the low-adaptation profile, there is clearly a more intense level of the temperament traits of activity (respectively: (1) $\mathrm{M}=18.34$, $\mathrm{SD}=4.9$; (2) $\mathrm{M}=14.58, \mathrm{SD}=5.08$ ) and sociability (respectively: (1) $\mathrm{M}=18.37, \mathrm{SD}=3.66$; (2) $\mathrm{M}=13.75, \mathrm{SD}=4.78$ ) and a significant lower occurrence of the traits of emotionality (respectively: (1) $\mathrm{M}=11.46, \mathrm{SD}=4.9 ;$ (2) $\mathrm{M}=15.16, \mathrm{SD}=3.8$ ) and shyness (respectively: (1) $\mathrm{M}=8.86, \mathrm{SD}=3.4$; (2) $\mathrm{M}=$ 11.25, $\mathrm{SD}=5.1$ ).

With regard to the resiliency variable, there were significant differences between those children of alcoholics at school age who made up the high-adaptation profile (1) and those from the low-adaptation profile (2). These differences applied to a sense of mastery $(\mathrm{t}(1.180)=5.6, p<0.001, \mathrm{~d}=1)$, the ability to establish satisfactory relationships with others $(\mathrm{t}(1.180)=5.4, p<$ $0.001, \mathrm{~d}=1)$, and a sense of control over their emotionality $(\mathrm{t}(1.180)=5.3, p<0.001, \mathrm{~d}=1)$ and a general psychological resiliency $(\mathrm{t}(1.180)=7.4, p<0.001, \mathrm{~d}=1.5)$. Those subjects from the high-adaptation profile (1), as compared to those from the low-adaptation profile (2), displayed higher levels of: a sense of mastery (respectively: (1) $\mathrm{M}=60.06, \mathrm{SD}=10.8$; (2) $\mathrm{M}$ $=46.18, \mathrm{SD}=11.8$ ), sense of relatedness (respectively: (1) $\mathrm{M}=$ 66.09, $\mathrm{SD}=12.9$; (2) $\mathrm{M}=51.89, \mathrm{SD}=11.53$ ), emotional reactivity (respectively: (1) $\mathrm{M}=51,91, \mathrm{SD}=13.26$; (2) $\mathrm{M}=35.53$, $\mathrm{SD}=14.78$ ), and an overall level of resiliency (respectively: (1) $\mathrm{M}=178.06, \mathrm{SD}=31$; (2) $\mathrm{M}=132,85, \mathrm{SD}=26.3$ ).

When comparing the results of the research among the distinguished profiles regarding strategies to cope with stress, it appears that in the school-age group, the significant differences are between dispositional $(\mathrm{F}(1.180)=8.58, p<0.01, \mathrm{~d}=1.2)$ and situational $(\mathrm{F}(1.180)=11.53, p<0.001, \mathrm{~d}=1.2)$ active coping strategies and discretionary strategies for seeking support $(\mathrm{F}(1.180=4.54, p<0.05, \mathrm{~d}=0.4)$. People who are welladapted to life, as compared to persons having difficulties, dis- play a higher level of disposable (relatively: (1) $\mathrm{M}=6.66, \mathrm{SD}=$ 3.19; (2) $\mathrm{M}=3.95, \mathrm{SD}=2.5$ ) and situational (respectively (1) $\mathrm{M}=6.49, \mathrm{SD}=3.54$; (2) $\mathrm{M}=3.77, \mathrm{SD}=2.63$ ) active coping strategies along with discretionary strategies for seeking support (respectively: (1) $\mathrm{M}=5.14, \mathrm{SD}=2.88$; (2) $\mathrm{M}=4, \mathrm{SD}=$ 3.5). The remaining differences are not statistically significant.

An analysis of the results also shows that academic skills clearly differentiate between the well-adapted subjects (those from Profile 1) and those children who have difficulty adjusting (Profile 2) $(\mathrm{t}(1.180)=6.2, p<0.001, \mathrm{~d}=1.3)$. Well-adapted subjects, from the high-adaptation profile (1), as compared to those from the low-adapted profile (2) who have difficulties, are characterized by better academic skills (respectively: (1) M $=4.32, \mathrm{SD}=0.75 ;(2) \mathrm{M}=3.2, \mathrm{SD}=0.88)$.

\section{Environmental Predispositions}

Comparisons between the profiles regarding parental social support show that within the school-age group there existed significant differences between the amount of obtained support from both the mother and the father (respectively from the mother: $(\mathrm{t}(1.180)=8.07, p<0.001, \mathrm{~d}=1.22$; from the father $(\mathrm{t}(1.180)=7.01, p<0.001, \mathrm{~d}=1)$. Those children who receive a higher level of support from the mother $(\mathrm{M}=61.29, \mathrm{SD}=$ $11.04)$ and from the father $(M=49.42, S D=18.89)$ tend to adapt far more effectively to the social environment as compared to those children from Profile 2 (respectively: (1) $\mathrm{M}=45$, $\mathrm{SD}=15.94$; and (2) $\mathrm{M}=30.51, \mathrm{SD}=17.38$ ). As regards to support from extra parental sources, those subjects in the youngest group exhibit significant differences between the profiles when it comes to support obtained from: teachers ( $\mathrm{t}(1.180)$ $=7.8, p<0.001, \mathrm{~d}=1.2)$, classmates $(\mathrm{t}(1.180)=9.32, p<$ $0.001, \mathrm{~d}=1.5)$ and a closefriend $(\mathrm{t}(1.180)=9.67, p<0.001, \mathrm{~d}$ $=1.5$ ). Those children at school-age from the high-adaptation Profile 1 show significantly higher levels of support from teachers $(\mathrm{M}=52.28, \mathrm{SD}=12.88)$, classmates $(\mathrm{M}=58.31, \mathrm{SD}=$ $13.43)$ and a closefriend $(\mathrm{M}=61.32, \mathrm{SD}=14.08)$ as compared to those children from the low-adaptation Profile 2 (respectively: support from teachers $(\mathrm{M}=36.18, \mathrm{SD}=14.93)$, classmates $(\mathrm{M}=36.79, \mathrm{SD}=14.8)$ and a closefriend $(\mathrm{M}=38.47$, $\mathrm{SD}=17,69)$ ).

\section{Correlates of Positive Adaptation}

The next stage tested which factors are the strongest correlates of positive adaptation among school-aged children of alcoholics. Through the use of a series of regression analyzes (hierarchical and stepwise), in which a large group of variables are taken into account - the potential correlates of positive adaptation in children can be established. The results from multiple linear regression analyses are displayed in Table 3. Due to the transverse nature of the research, it is not possible to identify which variables and individual and environmental factors are determinants of positive adaptation. The identification of resources and categorical risk factors would only be possible through a longitudinal study. However, it can be assumed that such contributing variables, from different levels of strength, help in the development of mental resistance in children of alcoholics .

At school-age, different factors, of various strengths, have an impact on resilience. In the analysis, the variables in question were related to positive aspects of health: life satisfaction and developmental tasks. 
Table 3.

A hierarchical regression analysis of the correlates of resilience indicators in school-aged children of alcoholics.

\begin{tabular}{|c|c|c|c|}
\hline & & $\begin{array}{c}\text { Life } \\
\text { Satisfaction }\end{array}$ & Developmental Tasks \\
\hline & & $\beta \quad \mathrm{R}^{2 \wedge}$ & $\mathrm{R}^{2 \wedge}$ \\
\hline \multirow{5}{*}{ Temperament } & Shyness & & \\
\hline & Activity & & \\
\hline & Emotionality & & -0.028 \\
\hline & Sociability & & 0.136 \\
\hline & $\begin{array}{l}\text { Communication } \\
\text { with mother }\end{array}$ & 0.151 & $0.231^{* *} 0.400$ \\
\hline \multirow{5}{*}{ Attachment } & Trust of mother & & \\
\hline & $\begin{array}{l}\text { Alienation from } \\
\text { mother }\end{array}$ & $-0.280^{* *} 0.024$ & \\
\hline & Paternal bond & & \\
\hline & Trust of father & & \\
\hline & $\begin{array}{l}\text { Alienation from } \\
\text { father }\end{array}$ & & \\
\hline \multirow{2}{*}{ Resiliency } & Sens of Mastery & 0.184 & \\
\hline & Sens of Relatedness & & $0.199^{* *} 0.094$ \\
\hline \multirow{5}{*}{ Support } & $\begin{array}{c}\text { Academic } \\
\text { achievement }\end{array}$ & & $0.214^{* *} 0.045$ \\
\hline & Teachers & & \\
\hline & Classmate & $0.220^{* *} 0.022$ & \\
\hline & Close Friend & & $0.206^{* *} 0.037$ \\
\hline & Activity Capacity & $0.227^{* *} 0.082$ & $0.180^{*} 0.013$ \\
\hline & ${ }^{2} \wedge$ total & 0.128 & 0.589 \\
\hline & & $\begin{array}{c}\mathrm{F}(5)=22.467 \\
p<0.001\end{array}$ & $\begin{array}{c}\mathrm{F}(7)=30.64 \\
p<0.001\end{array}$ \\
\hline
\end{tabular}

Note: ${ }^{* * *}$ Correlation is significant at the level of $0.001 ;{ }^{* *}$ Correlation is significant at the level of 0.01 ; ${ }^{*}$ Correlation is significant at the level of $0.05 ; \beta$ - standardized regression coefficient; $\mathrm{R}^{2} \_$_adjusted coefficient of determination.

The strongest explanatory variable to account for life satisfaction in school-age children of alcoholics is the presence of support received from colleagues and friends. These variables explained $10.4 \%$ of the variance. An important factor adversely affecting sense of life satisfaction is anger and hostility to the mother, however it is not an overly strong correlation $\left(\mathrm{R}^{2}=\right.$ $2.4 \%$ ). Many more variables explain developmental task performance within children of school age. The strongest predictor for this variable turned out to be good communication with the mother-this accounts for $40 \%$ of the variance of the results. Other important protective factors that explain a further $18 \%$ of the variance are: sens of relatedness, educational achievement, support received from a friend, and the individual's own activity capacity in his/her environment.

The results of the hierarchical and stepwise regression analysis that the proposed model explains about $13 \%$ to $60 \%$ of the variance of mental health in school-aged children of alcoholics; based on their individual characteristics, especially: resiliency, maternal attachment and educational achievements; and the characteristics of their surrounding environment, particularly support received from classmates and friends. The strongest predictors which support the process of resilience in the youngest group of children of alcoholics were found to be the level of maternal bonds, communication with the mother and low levels of alienation from her along, and the competence of the individual in relationships with others.

\section{Discussion}

As early as half a century ago in the theoretical models of alcoholism studies there was a tendency to view the disorder, and its underlying causes, as a phenomenon essentially subject to the influence of one factor. The dominant view was the child of an alcoholic would inevitably exhibit many of the problems and symptoms of psychopathology. One of the key research aims that were posed in this study was to answer the question of whether the population of children of alcoholics can be differentiated according to different aspects of mental health. It turned out that although parental alcoholism clearly affects mental the mental health of young people, about $40 \%$ of them exhibit adequate levels of adaptation to the conditions of life.

Our results support the hypothesis of the occurrence of resilience in the development of children at risk, and the children of alcoholics from Profile 1 of the research can be defined as adaptive individuals presenting a high-level of adaptation, despite exposure to adverse cumulative life experiences. There is the outstanding question of whether or not a well-adapted children of alcoholics differ from their less well-adapted peers from alcoholic families, in such a way that can warrant being labeled as resilient?

As it happens, it turned out to be possible. The research shows that resilient children of alcoholics are characterized by a specific system of individual predispositions and environmental factors. They are typically characterized by patterns of secure attachment with the mother. People who are healthy and welladjusted tend to have a positive temperament, which at school age, manifests itself as low level of emotionality and shyness, and a high level of sociability and activity. Compared to the low-adaptation profile (Profile 2), subjects from the high-adaptation profile (Profile 1) shows better educational achievement, and more initiative in pursuing their own interests and needs. Comparisons of the children of both profiles regarding support obtained from parents, teachers and classmates suggest that well-adapted children have much larger networks of close people, ready to help them in everyday situations.

The results of this study provide a basis for claiming a unique specificity of the process of resilience among children of parents with mental disorders. As noted by Luthar and Cicchetti (2000) the acquisition by children within high-risk groups of positive indicators of healthy mental-functioning is the result of great struggle and great effort; an effort much greater than in children of less dysfunctional families. A key resource for these children, to help them function efficiently and effectively, and to cope with chronic stress appears to be their innate biological equipment in the form of a more positive temperament, and especially a greater ability to regulate their emotions. This can, in a way, allow such individuals to protect themselves against the negative effects of parental alcoholism.

In various models of research on the subject of children of alcoholics, it is assumed that alcoholism in parents impairs their ability to effectively parent, which in turn increases the risk of improper adjustment in children, especially by entering into contact with peers showing deviations and engaging and escalating behaviors associated with the abuse of psychoactive substances (Windle \& Davies, 1999). With regard to youth risk behavior, researchers often use the concept of the multiple devel- 
opmental paths as an explanation of phenomena, such as the growing influence of peers and the importance of making make friends. This requires recourse to complex transactional processes: a model of peer socialization (abuse of psychoactive substances by peers directly affects young people) and peer selection models (youth selects peers with the most similar attitudes to their beliefs). The research of Curran, Stice, and Chassin (1997) confirmed the effects of the interaction with peers on developmental paths, both on the model of peer selection and peer socialization. The results provide data on the existence of a dynamic, two-way relationship between the use of psychoactive drugs by young people, and the similarity of the behavior of their peers. Likewise, it was also found that alcoholism in a parent also increases the risk of alcohol abuse. Other studies have revealed the existence of a developmental path of consisting of many variables (influencing the growth of developmental problems), such as the problems of addiction in parents, experiencing severe stressful life events, low levels of parental support, low self-control, and an increased tendency to relate to their peers in terms of deviant behavior (Wills et al., 1996). Our results support the conclusion that these factors, and their mutual configuration, allows for the potential prediction of development paths.

\section{Practical Implications}

The results provide a basis of reasoning regarding the dynamic structure of risk factors and resources in the lives of young people. Such an inference is possible in an indirect manner, rather than direct one, due to the transverse nature of the study. It turned out that the explanatory power of a complex matrix of individual and social factors is dynamic and varies at different stages of life. Among the youngest respondents the importance of the role of the school environment was especially marked, especially in children acquiring basic knowledge and the emergent skills of literacy, numeracy and writing. As children of alcoholics mature, their mental toughness is explained less by the role of social factors, and more by the predispositions of the individual, especially temperament and resiliency.

It is worth noting that the results obtained in the study indicate the specific role of parents in shaping the psychological resilience of children of alcoholics. During school age, even despite strong relationships with peers, parental influence is a major factor in the most important aspects of adaptation. The family remains the main venue of support and advice. Support from parents and good relationships with them, especially maternal, correspond to a higher index than the support that young people receive from their peers. The conclusions for practice indicate the essential role of parental relationship with children, and the importance of academic achievement during. Therefore, helping young students with problems in regards to school appears to be a real factor in the support that can be offered as part of prevention .

In conclusion, it is worth noting the need of including children in prevention programs specific to children in families with alcohol problems, as well as the taking into account the specificities of the stage of development at which the child is located. The content and scope of these programs should be drawn from knowledge of the relationships between the various risk factors (e.g., early acquired knowledge about the effects of alcohol and anti-social behavior) and protective factors (e.g., parental support).

\section{REFERENCES}

Armsden, G. C., \& Greenberg, M. T. (1987). The inventory of parent and peer attachment: Relationships to well-being in adolescence. Journal of Youth and Adolescence, 16, 427-454. http://dx.doi.org/10.1007/BF02202939

Boyce, W. T., Frank, E., Jensen, P. S., Kessler, R. C., Nelson, C. A., \& Steinberg, L., (1998). Social context in developmental psychopathology: Recommendations for future research from the MacArthur Network on Psychopathology and Development. Development and Psychopathology, 10, 143-164. http://dx.doi.org/10.1017/S0954579498001552

Caspi, A., Moffitt, T. E., Newman, D. L. et al. (1996). Behavioral observations at age 3 years predict adult psychiatric disorders-Longitudinal evidence from a birth cohort. Archives of General Psychiatry, 53, 1033-1039. http://dx.doi.org/10.1001/archpsyc.1996.01830110071009

Chassin, L., Pillow, D. R., Curran, P. J., Molina, B. S. G., \& Barrera Jr., M. (1993). Relation of parental alcoholism to early adolescent substance use: A test of three mediating mechanisms. Journal of $A b$ normal Psychology, 102, 3-19. http://dx.doi.org/10.1037/0021-843X.102.1.3

Cicchetti, D. (2006). Development and psychopathology. In: D. Cicchetti (Ed.), Developmental psychopathology (2nd ed.): Theory and method (pp. 1-23). New York: Wiley.

Curran, P. J., Stice, E., \& Chassin, L. (1997). The relation between adolescent alcohol use and peer alcohol use: A longitudinal random coefficients model. Journal of Consulting and Clinical Psychology, 65, 130-140. http://dx.doi.org/10.1037/0022-006X.65.1.130

Demaray, M., Malecki, C., \& Elliot, S. N. (2000). Child and adolescent social support scale. DeKalb, IL: Psychology Department, Nothem Illinois University.

Ellis, D., Zucker, R., \& Fitzgerald, H. (1997). The role of family influences in development and risk. Alcohol Health \& Research World, 21, 218-226.

Grzegorzewska, I. (2006). Realizacja zadań rozwojowych przez dzieci leczacych się alkoholików. Poznań: UAM.

Heath, A. C., Bucholz, K. K., Madden, P. A. F., Dinwiddie, S. H., Slutske, W. S., Bierut, L. J. et al. (1997). Genetic and environmental contributions to alcohol dependence risk in a national twin sample: Consistency of findings in women and men. Psychological Medicine, 27, 1381-1396. http://dx.doi.org/10.1017/S0033291797005643

Heitzeg, M., Nigg, J. T., Zucker, R. et al. (2008). Affective circuitry and risk for alcoholism in late adolescence: Differences in frontostriatal responses between vulnerable and resilient children of alcoholic parents. Alcoholism: Clinical and Experimental Research, 32, 414426. http://dx.doi.org/10.1111/j.1530-0277.2007.00605.x

Higuchi, R., Dollinger, G., Walsh, P. S., \& Griffith, R. (1992). Simultaneous amplification and detection of specific DNA sequences. Biotechnology (New York), 10, 413-417. http://dx.doi.org/10.1038/nbt0492-413

Jacob, T., \& Johnson, S. (1997). Parenting influences on the development of alcohol abuse and dependence. Alcohol Health \& Research World, 21, 204-209.

Jordan, S. (2010). The promotion of resilience and protective factors in children of alcoholics and drug addicts, BundesgesundheitsblattGesundheitsforschung-Gesundheitsschutz, 53, 340-346. http://dx.doi.org/10.1007/s00103-010-1035-x

Juczyński, Z., \& Ogińska-Bulik, N. (2009). Narzędzia pomiaru stresu $i$ radzenia sobie ze stresem. Warszawa: PTP.

Kaplan, H. B. (2005). Understanding the concept of resilience. In: S. Goldstein, \& R. B. Brooks (Eds.,), Handbook of resilience in children (pp. 39-47). New York: Springer Publishing.

Kendler, K. S., Neale, M. C., Heath, A. C., Kessler, R. C., \& Eaves, L. J. (1994). A twin-family study of alcoholism in women. American Journal of Geriatric Psychiatry, 151, 707-715.

Luthar, S. S., Cicchetti, D., \& Becker, B. (2000). The construct of resilience: A critical evaluation and guidelines for future work. Child Development, 71, 543-562.

http://dx.doi.org/10.1111/1467-8624.00164

McGue, M. (1997). A behavioral-genetic perspective on children of 


\section{GRZEGORZEWSKA, M. FARNICKA}

alcoholics. Alcohol Health \& Research World, 21, 210-217.

Oniszczenko, W. (1997). Kwestionariusz temperamentu EAS arnolda $h$. bussa i roberta plomina. Wersja dla dorostych i dla dzieci. Adaptacja polska. Podręcznik. Warszawa: PTP.

Prince-Embury, S. (2006-2007). Resiliency scales for children and adolescents: A profile of personal strengths. San Antonio, TX: Harcourt Assessment, Inc.

Seligson, J. Huebner, E., \& Valois, R. (2003). Preliminary validation of the brief multidimensional students' life satisfaction scale (BMSLSS). Social Indicators Research, 61, 121-145.

http://dx.doi.org/10.1023/A:1021326822957

Sroufe, L. A. (1997). Psychopathology as an outcome of development. Development and Psychopathology, 9, 251-268.

http://dx.doi.org/10.1017/S0954579497002046

Werner, E., \& Smith, R. (1982). Vulnerable but invincible: A longitudinal study of resilient children and youth. New York: Adams, Bannister and Cox.

Wills, T., McNamara, G., Vaccaro, D., \& Hirky, A. (1996). Escalated substance use: A longitudinal grouping analysis from early to middle adolescence. Journal of Abnormal Psychology, 105, 166-180. http://dx.doi.org/10.1037/0021-843X.105.2.166

Windle, M., \& Davies, P. T. (1999). Developmental theory and research. In K. E. Leonard, \& H. T. Blane (Eds.), Psychological theories of drinking and alcoholism (2nd ed., pp. 164-202). New York: Guilford Press.

Wolańczyk, T. (2002). Zaburzenia emocjonalne i behawioralne u dzieci i młodzieży szkolnej w Polsce. Warszawa: Akademia Medyczna.

Zucker, R. A., Kincaid, S. B., Fitzgerald, H. E., \& Bingham, C. R. (1995). Alcohol schema acquistition in preschoolers: Differences between children of alcoholics and children of nonalcoholics. Alcoholism: Clinical and Experimental Research, 19, 1-7. http://dx.doi.org/10.1111/j.1530-0277.1995.tb00982.x

Zucker, R. A., Wong, M. M., Puttler, L. I., \& Fitzgerald, H. E. (2003) The effects of resilience on developmental outcomes of sons of alcohol. In: S. S. Luthar (Ed.), Resilience and vulnerability (pp. 76104). New York: Cambridge University Press. 